\title{
THE IMPORTANCE OF INNOVATIVE TECHNOLOGIES IN THE DEVELOPMENT OF MINING STUDENTS' LEXICAL COMPETENCE
}

\section{Khusnora Saydullaeva}

Phd Student Navoi State Pedagogical Institute, Uzbekistan

\section{ABSTRACT}

This article expresses the significance of innovative technologies in the educational process as well as promotes the probable advantages and disadvantages of these technologies during the lessons. Moreover, the paper identifies the importance of development of oral speech among students in mining field and presents the types of technologies that can be used in the classroom.

KEYWORDS: - Technology, innovation, innovative technologies, videos, internet, mining, students, learner, educational process.

\section{INTRODUCTION}

In the learning process, the active attitude of the student to learning is important. And here the professional skill of the teacher, his teaching methodology and the pedagogical technologies used are put forward. At all levels of education, technological advancements are having a big impact.

The traditional classroom is being disrupted by online courses, instructional aids, educational software, social networking tools, and other developing technology. Understanding how technological developments affect students, teachers, and even all types of elementary and secondary schools is crucial to establishing methods and procedures for managing and implementing technology in the classroom.

Modern innovative technologies help the teacher make the learning process more effective, take into account the level of preparedness of students, their physical and mental capabilities, and the profile of learning. Education systems evolve slowly for a variety of reasons, some of which are reasonable (social cohesion, the transmission of enduring values, political pressure), yet technology (and its promise for learning) is rapidly improving.

\section{THE MAIN FINDINGS AND RESULTS}


CURRENT RESEARCH JOURNAL OF PEDAGOGICS 2(12): 143-148,

December 2021 DOI: https://doi.org/10.37547/pedagogics-crjp-02-12-29

ISSN 2767-3278

(C)2021 Master Journals

Crossref doi) 81 Google

Accepted 23 ${ }^{\text {th }}$ December, 2021 \& Published $28^{\text {th }}$ December, 2021

In such a situation, the success of mainstreaming processes is frequently the most important determining factor in transforming practice and maximizing the benefits of ICT. To avoid mainstreaming efforts that are likely to fail, mainstreaming methods should not only encourage the adoption of novel behaviors and technologies, but also increase the detection of risks and hurdles.

Modern educational technologies are designed to:

- to make the pedagogical process of teaching and educating students effective;

- to reduce energy consumption both on the part of teacher and students;

- to develop the motivation of trainees by changing the students' position from passive to active;

- to bring the process of education quality management to a new level;

Many teachers in their practice rely on the introduction of such technologies, which are aimed at guaranteed achievement of the intended results. The choice of technology in educational and extracurricular activities depends on the goals and objectives set by the teacher at a certain stage. The main goal of using modern technology is to provide a motivated choice of options for solving the problem.

The entire methodological system is built on the basis of taking into account the theory of teaching vocabulary which is based on the development of lexical competence, relying on data from related sciences (didactics, psychology and linguistics) and leading methodological principles, the implementation of which is possible subject to such conditions as the rational selection of vocabulary and grammatical forms, their repetition, activation all types of speech activity (listening, speaking, reading and writing), a reasonable dosage and consistency in the arrangement of theoretical information and practical tasks.

One of the most important indicators of the level of a person's culture, his thinking, intelligence is his speech. The development of speech should go parallel to the development of logical thinking, correspond to the age characteristics of students and contribute to an increase in the general culture in terms of mining, that is, the sphere of specialization.

In the development of speech skills, three directions are clearly distinguished: work on a word (lexical level), work on a combination and a sentence (syntactic level), work on coherent speech (text level).

Moving onto the next point, we have to mention the primary principles of speaking:

- Reliance on conscious perception and creative reproduction of the content and linguistic material of information;

- Taking into account the knowledge of students overcoming difficulties;

- Interrelation of listening, speaking, reading and writing;

- Inseparability of the content, logical, linguistic and pronunciation aspects of oral speech;

- Extensive use of the situational teaching method in order to approximate the speech communication of students to the natural form of expression;

- The novelty of speech material, arousing interest in the content and form of speech, encouraging the use of many presentations and speeches during lessons;

- Advance development of speech knowledge of grammar;

- Inclusion in the "sounding environment" not only the words of the teacher and students, 
CURRENT RESEARCH JOURNAL OF PEDAGOGICS 2(12): 143-148,

December 2021 DOI: https://doi.org/10.37547/pedagogics-crjp-02-12-29

ISSN 2767-3278

(C)2021 Master Journals

Crossref di) 81 Google

Accepted 23 ${ }^{\text {th }}$ December, 2021 \& Published $28^{\text {th }}$ December, 2021

but also all types of sound recording.

These principles imply the leading role of the teacher in the process of teaching students, determine the content of teaching oral speech, its material, teaching methods, and take into account the peculiarities of the native language.

Thus, the development of oral speech among mining students is inextricably linked with the communicative function of the language and should be focused on instilling practical skills in various types of speech activity: listening, speaking, reading and writing.

Types of speech activity:

- listening

- speaking

- reading

- writing

The main goal of the multifaceted development of oral speech among students with the help of innovative technologies is to teach students to freely use the language orally in various areas of language communication.

Solving the above problems, teachers in their practice should use non-traditional, creative pedagogical technologies that increase the motivation of learning and students' interest in the professional subjects through a foreign language, create an atmosphere of creative cooperation and competition, give them a sense of creative freedom and, most importantly, bring joy.

In the lesson, you can use other innovative technologies, such as the Internet, video. The advantages of these forms of work are:

- Improving the skills and abilities of dialogical communication in their sphere;

- Expanding vocabulary with the vocabulary of the modern language in their specialty;
- Acquaintance with cultural knowledge, including speech etiquette, culture features, traditions of the country of the target language;

- The formation of a stable motivation for the foreign language activity of students in the classroom on the basis of the systematic use of "living" materials in the specialty;

- Increasing the individual and group work of students during the classes.

Creative speech-thinking activity in teaching dialogical communication, as well as work with innovative technologies, allows students to engage even the most passive, low-level students and increase their interest in the subject through a foreign language.

So, we can conclude that:

- The teacher's practical activity should be aimed at developing a variety of speech actions;

- Teach vocabulary in a dialogical form on cues that support two-way activity;

- To simulate dialogical communication, create communicative situations in roleplaying games and methods of collective interaction;

- To increase motivation and interest in learning foreign languages, use media material and the Internet in the learning process.

Innovation (from Latin in - in, novus - new) means something new, newly developed and created thing. The main indicator of innovation is the progressive beginning in the development of the university students' lexical competence in comparison with the established traditions and mass practice.

Active learning is based on the fact that the students are increasingly faced in real life with 
CURRENT RESEARCH JOURNAL OF PEDAGOGICS 2(12): 143-148,

December 2021 DOI: https://doi.org/10.37547/pedagogics-crjp-02-12-29

ISSN 2767-3278

(C)2021 Master Journals

Crossref dof 81 Google

Accepted 23 ${ }^{\text {th }}$ December, 2021 \& Published $28^{\text {th }}$ December, 2021

the need to solve problem situations.

Teaching students, the skills of vocabulary leading to the enhancing lexical competence using innovative technologies involves the introduction of a number of psychological approaches, such as: cognitive, positive, emotional, motivational, optimistic, technological. All of these approaches are addressed to the personality of the student.

To achieve the maximum effect, it is necessary to use a wide range of innovative, including, of course, various media educational technologies in the educational process.

The prospects for the use of Internet technologies today are quite wide. This could be:

- $\quad$ correspondence with residents of Englishspeaking countries, via e-mail;

- $\quad$ participation

in

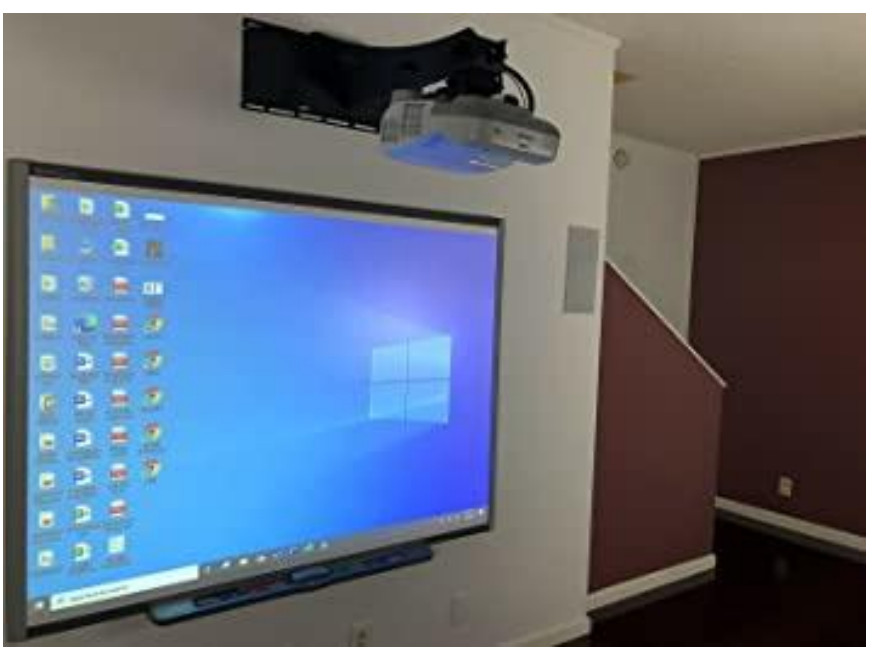

Moving onto the next part, we have to identify prominent means of integrating innovative technologies into the teaching-learning process.

The first innovation that can be used in this procedure is the usage of Smart boards. They are usually considered to be useful in making students' understanding on the topics better and international Internet conferences, webinars, online-seminars and other network projects of this kind;

- $\quad$ creation and placement on the network of sites and presentations - they can be created jointly by the teacher and the student. In addition, it is possible to exchange presentations between teachers from different countries.

As the pedagogical experience shows, the work on the creation of Internet resources is interesting to students for its novelty, relevance, and creativity. The organization of the cognitive activity of students in small groups makes it possible for each student to show their activity. 
CURRENT RESEARCH JOURNAL OF PEDAGOGICS 2(12): 143-148,

December 2021 DOI: https://doi.org/10.37547/pedagogics-crjp-02-12-29

ISSN 2767-3278

(C)2021 Master Journals

Crossref dof 81 Google

Accepted 23 ${ }^{\text {th }}$ December, 2021 \& Published $28^{\text {th }}$ December, 2021

their speaking competence.

The next method of implementing modern technologies in the classroom is giving the students right to interact actively and use oral speech as often as possible. In accordance with this method, which is called in other words flipped classroom method, the teacher works as a passive member of the lesson, while students prepare the material for the lesson beforehand and present it in front of their group mates. The following strategy that we can follow in the educational process is the integration of different types of projects within small groups on the topics of interest. This very task results in encouragement of student interaction and student's familiarization with difficult terms and language that may be useful in their professional field. For example, offering group homework or encouraging students to collaborate on plays, presentations, and other reports are just a few examples.

Today, collaboration as a style of education is gaining acceptance as an effective teaching technique in which the educators play the role of guides, mentors, and supervisors for the students, once again putting the burden on the group of students. It also teaches empathy, negotiation, teamwork, and problem-solving to students.

On the other hand, there are plenty ways of developing speaking abilities of students by the means of virtual reality. Virtual Reality technology aids students in learning by allowing them to engage with a 3D environment. Instead of taking students through a speaking class or a class in their respective industries, teachers can use 3D technology to get to know native speakers, familiarize themselves with new professional language, or practice their speaking talents.

Virtual reality technology provides students with a unique opportunity to learn in an immersive environment that will leave an indelible mark on their minds. It makes learning more enjoyable for students and aids their retention of material for longer periods of time - both important considerations when considering effective classroom teaching approaches. Another type of strategy in innovative technology implementation during classes of mining students can be 3D printing technology (Pic. 2 below). 3D printing can be used as a teaching tool by teachers who are looking for new ways to enhance lexical competence.

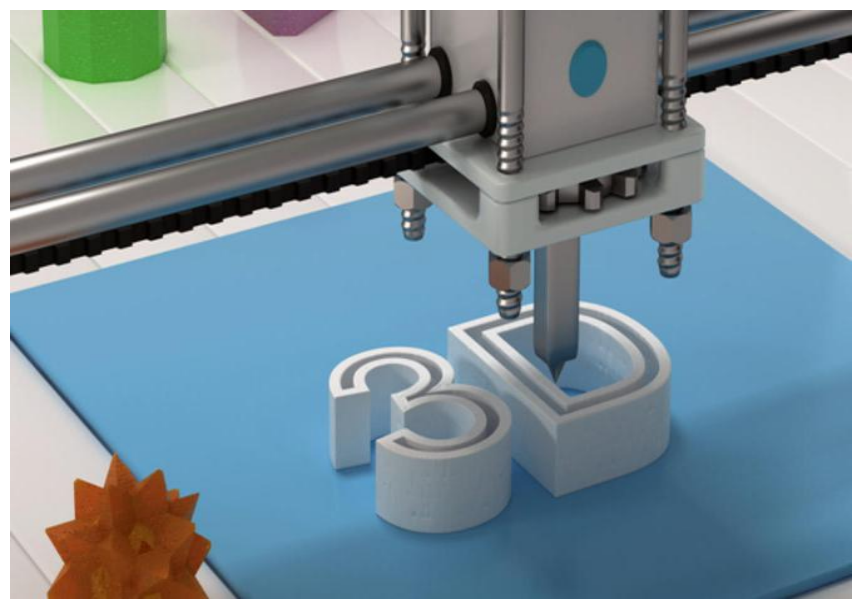

This technology is quickly gaining traction around the world, particularly in higher education institutions where 3D printers are utilized to construct prototypes and simplify complex topics.

Teachers can employ 3D printers in lower-level groups to teach lexical material that was traditionally taught through textbooks, allowing students to develop a greater comprehension of the concept-especially in STEM (Science, Technology, Education and Mathematics) courses, which are considered to be the primary one for students approaching the mining field.

In addition, there is a method named cloud computing - variable of innovative technologies. Bringing technology into the classroom helps 
CURRENT RESEARCH JOURNAL OF PEDAGOGICS 2(12): 143-148,

December 2021 DOI: https://doi.org/10.37547/pedagogics-crjp-02-12-29

ISSN 2767-3278

(C)2021 Master Journals

Crossref do: 81 Google

Accepted 23th December, 2021 \& Published 28 ${ }^{\text {th }}$ December, 2021

educators to try out new teaching strategies. Teachers can save important classroom resources such as lesson plans, notes, audio lessons, videos, and assignment details on the school cloud using cloud computing. Students can then access this from the comfort of their own homes at any time, bringing the classroom back to them with the click of a mouse. It also guarantees that students who are absent from class due to illness or other reasons are kept up to date at all times. It eliminates the need for students to tote about hefty textbooks and allows them to learn when, when, and at their own pace. The use of technology in the classroom allows students to be exposed to a variety of stimuli and creates an environment conducive to activitybased learning. It adds interest to the classroom's subject and makes learning more effective and enjoyable.

\section{Conclusion}

Technology provides instructors with an almost limitless set of tools that they can use to meet the needs of their students. While this article highlights a few such sites, a teacher looking for efficient teaching methods in the classroom will find a wide variety of updated solutions by turning to the current technologies.

\section{REFERENCES}

1. Bahadorfar, Maryam \& Omidvar, Reza. (2014). TECHNOLOGY IN TEACHING SPEAKING SKILL. International Journal of Multidisciplinary Research Review. 2. 9-13.

2. Brown, G. and G. Yule. (1983). Teaching the Spoken Language. Cambridge: Cambridge University Press

3. J. Voogt. Consequences of ICT for aims, contents, process and environmental of learning. U.Hameyer(eds). Curriculum landscapes and Trends. Dordecht: Kluwer.
2003

4. Kang Shumin In Jack Richards C. and Willy A. Renandya. 2002. Methodology In Language Teaching. USA: Cambrige University Press.

5. M. Drent. On the road to innovative use of ICT in teacher education. Doctoral dissertat ion. Enschede: University of Twente. 2005

6. McGraw-Hill Ur, P. (1996). A Course in Language Teaching, Practice and Theory. Cambridge University Press.

7. Nunan, D. (2003). Practical English Language Teaching Teacher's Text Book.

8. Pourhossein Gilakjani, A. (2013). Factors contributing to teachers' use of computer technology in the classroom. Universal Journal of Educational Research, 1(3), 262267. doi: 10.13189/ujer.2013.010317

9. Richard, j. (2008). Developing classroomspeaking activities, from theory to practice.

10. Zhang, P., \& Aikman, S. (2007). Attitudes in ICT Acceptance and use. In J. Jacko (Ed.), Human-Computer Interaction, Part I (pp. 1021-1030). Syracuse, NY: Springer-Verlag Berlin Heidelberg 